\title{
Maintaining the scene: entrepreneurship in Berlin's artistic sectors.
}

CUNNINGHAM, J., TOLONEN, K.-M.

2019 


\title{
MAINTAINING THE SCENE: ENTREPRENEURSHIP IN BERLIN'S ARTISTIC SECTORS
}

\author{
James Cunningham \\ Aberdeen Business School, \\ Robert Gordon University, \\ Aberdeen, AB10 7QE, \\ Scotland, United Kingdom \\ E-mail: j.e.a.cunningham@rgu.ac.uk \\ Kaisa-Maija Tolonen \\ Aberdeen Business School, \\ Robert Gordon University, \\ Aberdeen, \\ AB10 7QE, Scotland, United Kingdom
}

Paper accepted for publication in the International Journal of Entrepreneurship and Small Business, October 2017. This is a revised and expanded version of paper presented at IECER 2017, Siegen, Germany.

\begin{abstract}
Berlin is a city famous for its artistic culture and uniquely inspired history, building a hotbed of creativity to draw talent from across the world. Our research problem is that, notwithstanding abundant creativity, Berlin's economy struggles behind other capital cities, and indeed Germany's national economy. We offer an explanation for this situation in the way entrepreneurship functions in Berlin's artistic sectors. We apply a mixed embeddedness lens to find the key role of the intermediary driven by cultural agendas and the maintenance of artistic integrity. Thus, economic goals are deprioritised. Our findings have implications for understanding the creative industries in Berlin, and more broadly, they demonstrate the importance of social and spatial context in determining the nature of entrepreneurial activity.
\end{abstract}

Keywords: cultural entrepreneurship, creativity, Berlin, mixed embeddedness, social context, artists, noneconomic, ethnography, qualitative data, social construction. 


\section{Introduction}

Since German unification, and in many ways even before this, Berlin has garnered a reputation as a cultural petri dish. Historical concentrations of various cultural identities led to the city becoming a magnet for artists, musicians, designers, and all other forms of creative soul (Novy and Colomb, 2013). Yet this creative milieu has not directly translated into the economic success which Florida (2014) would predict; a situation brutally pointed out by the Cologne Institute for Economic Research (2016) who show a depressant effect of Berlin's economy on Germany's income per capita. Thus, it seems that Berlin's famously creative space does not foster creative entrepreneurship of the type to develop economic growth (Lee et al., 2004). In this regard, Berlin is a place of low economic rationale, which from an economic perspective can mean that entrepreneurial opportunity is restricted (Shane and Venkataraman, 2000). However, instead of following this assumption, we take inspiration from Johnstone and Lionais (2004) by suggesting that creative entrepreneurship will still take place in such a context, but it will take on more novel responses to the environment, where interactions of noneconomic forces may be more useful in understanding the entrepreneurial phenomenon than outcome-derived explanations (Anderson, 2015; Baker and Nelson, 2005; Pret et al., 2016).

Lange et al. (2008) draw attention to the unique 'scene' of Berlin's creative entrepreneurship. A high proportion of rent-controlled properties couple with a relatively young and international population, making Berlin attractive for artists and creative types looking for institutional support and inspirational nourishment. This has led to the emergence of an industry based on combining cultural expression with tradable goods (Montgomery, 2005), with one in five of the city's enterprises attributed to the cultural industries - over 28,000 businesses and growing (Senatsverwaltung für Wirtschaft und Technologie, 2014). Ertel (2006) suggests that such 'culturalpreneurs' are often micro in scale and therefore depend almost entirely on localised knowledge and non-declared exchanges of services amongst peers, thus making the contextual space important in providing sustenance to the 'business'. A closer look at formal data of Berlin's Kunstmarkt shows over $74 \%$ of enterprises here declared as freelance/sole traders (Senatsverwaltung für Wirtschaft und Technologie, 2014), suggesting that the arts sectors are particularly characterised by independent individuals, and thus rely on peer networks and knowledge exchange.

However, this mostly informal artistic spark in collective entrepreneurial endeavour operates within a unique context of economic malfunction, where Berlin's artistic sectors often relish in their resistance to growth and economic performance (Novy \& Colomb, 2013). Artists are rooted to their scene in order to survive, but in this localisation of creativity they are often seen as the "groundbreakers of gentrification", a process credited to the destruction of the vitality in which artistic individuals thrive (Atkinson, 2003, p.2348). It seems that artistic scenes struggle with a paradoxical challenge, where success in economic development breeds cultural regeneration, and in turn the destruction of the space which supports them (Tironi, 2009). Harvey (2001) characterized these 'creatives' as socially antagonistic, playing a role in the growing contestation of neoliberal agendas in urban locales. This charactarisation may help explain why entrepreneurship research has traditionally neglected such areas, preferring instead to focus on entrepreneurial activity more easily explained in economic terms. In this article, we address this neglect, and investigate the character of entrepreneurial activity in Berlin's artistic scene. Specifically, we wonder how entrepreneurship functions in such a context, and is maintained under a resistance to economic growth. 
In order to explore this, we examine the roles of various cultural producers in the city's artistic sectors. These include artists, musicians, independent designers, gallery owners, and other enterprises engaged with artistic endeavour. The research design adopts a two-stage approach: first, an ethnographical account is presented, which seeks to identify key actors of the city's arts scene, and second, a more specifically targeted approach is taken towards conceptualising how the scene functions at an interactionist level. The socially constructed identities of individual actors are assessed in order to build a picture of how they see themselves in relation to their environment. A mixed-embeddedness framework is used to help understand how the various positons interact, and the role and nature of entrepreneurship. As such, this article moves away from entrepreneurship as an individualised activity, and instead looks to the co-creation of an entrepreneurial phenomenon (Anderson et al., 2010).

The remainder of the article is structured as follows. First, the nature of the artist as a cultural producer is explored. Second, the importance of social and spatial place is highlighted as a contextually informative element in understanding entrepreneurship. Then, the notion of social embeddedness is introduced as an explanatory framework for the nature of entrepreneurial activity. The two-stage methodology is discussed, along with the epistemological assumptions made to apply this conceptual framework. Finally, key findings are presented and integrated in the surrounding literature to illuminate entrepreneurial functioning in Berlin's artistic scene, with view to shedding light on the economic curiosity of high levels of cultural creativity, yet low economic development.

\section{The artist and entrepreneurship}

There is an oft-cited tension between artists and the economic management of their creative talent (Eikhof \& Haunschild, 2006). Creative entrepreneurs in the artistic spheres are said to have to straddle and reconcile two conflicting identities, one of the artist, and one of the small business owner (Menger, 1999). Following Swedberg (2006), entrepreneurship in such a context can be seen as a mechanism relating the artistic, which in the contemporary form often takes responsibility for offering existential explanations, to the economic, in the wages and profits generated from some unique combination of resources. Artists care deeply about their 'product', as Caves (2000) suggests, they will be willing to invest more time and energy in producing a piece than any expected 'reward' for its economic sale. This, therefore, limits traditional accounts of an economic explanation to entrepreneurship. Moreover, the infinite variety of artistic production makes the evaluation of opportunity structure very difficult, with divergent tastes and unpredictable trends making casual rationality a near impossibility (Sarasvathy, 2001). Thus, the nature of entrepreneurship in the artist sectors can be expected to be very different to what is found in the more traditionally researched industries (Phillips, 2010), as greater emphasis on entrepreneurial contingency can be expected, and the product emanates directly from the imagination of the individual, as opposed to any market-based forces.

Much of the current research on the arts-entrepreneurship interface focuses on entrepreneurially orientating the artist towards market opportunities. For example, Fillis and Rentschler (2010) discuss how the variety and uniqueness of creative offerings can be weaponised in the competitively strategic arena through effective marketing. As part of this strategic differentiation, reputation based on how individual producers value and believe in the craft of their artistic endeavour becomes key is establishing their image and identity (Fillis, 2003). Tregear (2003) also suggest that, as opposed to resisting economic and market-based agendas, small craftspersons 
prioritise lifestyle goals and adherence to 'craft principles' as a way of demonstrating the market value of the offering (Colbert, 2003). As such, much of this work looks to ways of commercialising the individual artistic producer. Where we used to consider art for art's sake, artists are now transitioned into forms of self-employed entrepreneurialism in order to assert their art on society, and indeed the economy (Ellmeier, 2003). However, Hausmann (2010) contends that this is inappropriate, as an artist's logic will look to protect their non-economic aims and what they see as their artistic integrity. Thus, artists may purposefully delimit the influence of classically entrepreneurial mind-sets, particularly around building a market orientation which they see as unconnected to their raison d'etre (Colbert, 2006). In this study we seek to extend these individualised views on the artistic entrepreneur by taking inspiration form recent literature on context.

\section{Entrepreneurship in the social context}

Examining the complexities of entrepreneurship in the arts sectors from an individualised perspective is problematic, particularly as it is the interaction with a surrounding context of peers which appears important. In order to accommodate this, we follow Welter (2011) and use the social context of the Berlin art scene as a lens to inform our study of entrepreneurial behaviour and further what is already known of internalised existential crises in artistic entrepreneurs (Novy and Colomb, 2013). We look to the lived experiences of those engaged in artistic entrepreneurial endeavour as a way of understanding how the scene works, with particular emphasis on the drivers of entrepreneurship, as many of the opportunities presented for artists would appear less than lucrative, or economically non-rational (Baker \& Powell, 2016).

Berlin provides us with a setting rich in potentially influential context. A vast history of artistic and creative endeavour combines with a unique geopolitical background to offer the inspirational attributes so important for creativity (Drake, 2003). Our intention, however, is not to objectify this context, but instead look to examine how aspects of the social and spatial, in the Berlin creative scene, impact on entrepreneurial activity (Fletcher \& Selden, 2016). Thus, we take inspiration from Van Gelderen et al. (2012), by looking to the relationships between individual parts and the ultimate whole. A situational and context-specific approach to the examination of entrepreneurship implicates a lot of what is known on the importance of networks (Hoang \& Antoncic, 2003) and localised social capital (Westlund \& Bolton, 2003; Gedajlovic et al., 2013). However, instead of focusing on what helps to build successful entrepreneurial endeavour, we look to use these concepts to offer a more useful understanding of entrepreneurship in a context where market conditions are less established, but the environment is ostensibly creative (Smallbone \& Welter, 2006). As such, we look to contribute to the growing research on context specificity and the embeddedness of entrepreneurial phenomena (Schmude et al., 2008).

\section{$4 \quad$ Mixed embeddedness}

Entrepreneurship exists by the interactions that take place between and within the structure and context of the individual entrepreneur's surroundings (McKeever et al., 2014). The relationships between the entrepreneur and her surroundings can be explained to some extent by the embeddedness metaphor (Granovetter, 1985). By seeing entrepreneurial creativity as a phenomenon nested in localised patterns of social and institutional relations, an embeddedness perspective allows us to look to the interactions of these elements (Peltoniemi, 2009; Tamasy, 2010). 
Kloosterman et al. (1999) suggest that there are at least two aspects of an entrepreneur's embeddedness related to commercialisation and economic growth, termed mixed embeddedness. Frist, the founding entrepreneur's social context has the ability to provide a resource base upon which the enterprise can be built. For instance, entrepreneurs in ethnic minority groups may find that as they are embedded structurally in family relations or socially with co-ethnic associates, they are offered a sympathetic and patient support for the business (Barrett et al., 2001), allowing the business to develop a sustainable and often distinct offering. The second aspect of mixed embeddedness relates to awareness of, and access to, the market opportunity structures available for a business to serve (Kloosterman \& Rath, 2001). Again referring to ethnic minority entrepreneurship, Kloosterman and Van der Leun (1999) note that ethnic capital, as well as offering a sustainable resource base, may also provide a naturally understanding market for dealing in co-ethnic goods and services. Thus the entrepreneur becomes sufficiently embedded in their own social and relational surroundings to provide resource for the firm, but also is embedded in a market-based opportunity structure to sufficiently commercialise the offering (Kloosterman, 2010). However, many authors who have applied this framework to ethnic minority entrepreneurs have found the weighting of embeddedness to be skewed towards the social context and culture as opposed to the market-based opportunity culture (Ram \& Jones, 2008; Masurel et al., 2002), prompting calls for ethnic minority entrepreneurs to break out of their ethnic enclaves in order to achieve economic growth (Rusinovic, 2008).

While this conceptualisation has evolved from an understanding of ethnic minority entrepreneurs (Ganzaroli et al., 2013), many of the ideas resonate with entrepreneurship in the artistic sphere. For instance, the tension between artistic and commercial cultures (Eikhof \& Haunschild, 2006) is reminiscent of the tension between ethnic and mainstream cultures. Moreover, issues of artistic self-image and a reluctance to subscribe to economic processes of entrepreneurial growth (Hausmann, 2010), mean that legitimacy is gained (Lounsbury \& Glynn, 2001) and success measured (Colbert \& Courchesne, 2012) through intra-sector acknowledgment and networking (Konrad, 2013). This echoes much of the co-ethnic enclave arguments, where the worry is entrepreneurs become entrenched in their ethnic cultures to such an extent that it becomes difficult to break out, and may ultimately result in the bounding of creative enterprise. We therefore see great benefit in 'borrowing' the concept of mixed embeddedness from the ethnic minority literature and applying it as a potentially explanatory framework to the creative sectors of Berlin.

\section{$5 \quad$ Methodology}

We use a two-stage methodological approach in order to examine the embeddedness of entrepreneurship in Berlin's artistic scene. Frist, we build an ethnographic account of those engaging in artistic activities. Such an approach allows us to examine the various actors and their role in the entrepreneurial process, thus uncovering the interconnectedness of the individual in context (Calás et al., 2009; Alvesson \& Deetz, 2000). Data were collected through a combination of planned observations and semi-structured narrative interviews (Dana \& Dana, 2005). These data are analysed using inductive techniques rooted in the grounded theory approach (Corbin and Strauss, 1990; Glaser and Strauss, 1967) and looks to establish the constructed identities of the individual actors of the artist scene. The aim of this first stage is to uncover the various roles played by individuals (akin to that seen in Bruni et al., 2004), allowing us to consider their positions using the mixed embeddedness framework. Thus, we can sketch the various individuals of the scene according to the extent of their embeddedness in artistic or market-based cultures. From this 
sketch, we are able to highlight the key area of importance in addressing our research problem in stage two of the study.

In stage two, we specifically target those individuals found to be at the nexus of the artistic and market-based cultures, and seek to understand the scene's limited economic development. In this second stage, we again take a semi-grounded approach to uncover the identity and role of these individuals in further detail and develop an explanation on the nature of their entrepreneurial activity. We follow Anderson and Jack (2002) by utilising Silverman's (2013) constant comparison method to first identify exploratory themes from stage one of the study, along with the surrounding literature, and then supplement these with further, more targeted, interviews looking to observe the role of entrepreneurship as embedded in both the artistic and market-based cultures. The two-stage approach to data collection and analysis allows us to interact with different contextual dimensions (Chlosta, 2016), using the framework of mixed embeddedness as an explanatory guide.

\subsection{Data collection and sampling}

In order to provide an ethnographic account of the artistic scene in Berlin, the first author travelled with a non-academic companion to investigate the various aspects of art and cultural production in the city. This included participating in the ' 48 Stunden Neukölln' Kunstfestival - a 48 hour event for artists in the Neuköln area of the city to open the doors of their studios, galleries, etc. and engage with visitors and surrounding community. We took time to interview one of the artists prior to the festival and also a more detailed interview a few days after. During the event itself, the first author, with non-academic companion (herself a designer and native of Berlin), explored the broader event and spoke to a number of artists, photographers, designers, on their art, intentions for the event and their enterprise. These discussions though not full research interviews, allowed us to observe the variety of cultural production evident in the area. An entire afternoon was spent inside one studio, which was home to a designer of contemporary wall hangings (our pre- and post-event research participant), a portrait painter, a fashion designer, and a musician. The extended time spent in this studio was vital as it allowed for active observation of the artists interacting with each other and with the broader public/customers, it also allowed for more structured and extended interviews with the artists than was possible in the broader exploration of the event. The remainder of the first stage data collection entailed semi-structured interviews with other cultural producers in the city. These were initially identified by touring the known artistic areas of Berlin, and subsequent snowball sampling. In-depth interviews with a total of 6 individual participants took place at this stage of the study, combined with immersive observations, shorter discussions and researcher case notes.

In the second stage of the study, a more purposeful sampling approach was taken, whereby those individuals found to be at the intersection of the artistic and market-based cultures became our focal point of interest. The second author travelled to Berlin after the initial analysis of stage one data and sought to examine in more detail the nature of entrepreneurs dually embedded in both the artistic and commercial cultures. Participants at this stage of the work had to meet certain criteria. First, they should be engaged in selling artefacts of cultural production from the Berlin area. This should be original artistic production from Berlin-based artists, such as: painting, photography, literature, design work, sculpture and furniture of bespoke design. Second, these cultural artefacts should be actively sold to the broader commercial market, whether in a physical location, such as 
a gallery, or through some other way of engaging with the commercial market. From this stage of the data collection, 9 in-depth semi-structured interviews took place.

The two-stage approach to data collection led to a total of 15 in-depth interviews with individuals engaged in cultural production in Berlin, and many case notes from observations both during the Kunstfestival and more broadly from informal discussions during stage one. The use of a nonacademic companion, who was aware of the artistic process and the intricacies of the Berlin area, was vital in providing a sounding-board during the collection of case notes and in gauging the validity of observations. Also, the use of a second researcher in stage two allows for a second interpretation of findings, thus providing some confidence on the reliability of results.

The following findings present a summary of the inductive themes from both stages of the study. Also, we look to integrate findings with the extant literature following constant comparative analytical techniques. Ultimately, we look to provide some understanding of how entrepreneurship functions in the creative scene of Berlin, and aim to shed light on our research problem of high cultural capital yet low economic success.

\section{$6 \quad$ Findings: Stage one}

In order to uncover the role of entrepreneurship, an initial ethnography of the cultural scene in Berlin is presented. Three forms of cultural producers are proposed from this first stage of the study: the artist; the intermediary; and the commercialised business. This ethnography is mostly presented in raw data form, with qualitative excerpts from participants and reflective field notes from the researcher. However, some engagement with theoretical concepts is also presented in order to explain the conceptual development. After introducing the three protagonists of Berlin's cultural scene, these will be viewed through the lens of mixed embeddedness, in order to position and help understand the role of entrepreneurship.

\subsection{The Artists}

'Artists come to Berlin because it's cheap and there's lots of free space, that's why I came here, but I don't know anyone that's made a living through creative arts', Casandra tells me as she explains the two days a week she devotes to her wall-hangings, when she is not working as an office manager for an IT start-up. 'I'll go into the wall-hangings as my main job but I don't really have a plan for the future, I'm just waiting to see what happens just now'. She shares a rented studio space with Joe, a portrait artist from Australia, and Steve, a musician and also from Australia. 'It's the cultural as well', Steve explains as we drink beer on the street outside of the studio. 'I like how inspiring it is. I'm not doing art, I'm doing music here so it's creative. Just walking through the streets, seeing graffiti everywhere and just cool spaces like parks and everything, it's just inspiring'. Joe adds to the importance of Berlin, but sees a more structured connection to the events that take place in the rest of the city. He suggests, 'the thing with art is that it's really accessible here, you can just get a bus really cheap and go and see a really good show - that said, there's also a lot of really bad art here... It's the wall. The wall created this environment and it became a mecca for anti-establishment creativity'. 'That's it!', Steve exclaims, 'it's what happens to you in the time when you're not painting, it's just inspiring... Everyone's like stick it to the man. It snowballs from the initial resistance, people see that and feed off it'. Our artists see themselves as part of this movement of resistance. 
Many studies have commented on the local 'buzz' of an area, the undefinable feel that generates an identification and inspires creativity (Storper \& Venables, 2004; Helbrecht, 2004). But there seems to be more than simple inspiration. The studio co-habitants, although pursuing very different art-forms, appear to take energy from each other and the broader locale. 'I reckon its being around a lot of creative people doing really creative things, like it gets you amped to do your own creative thing as well... with here, the normal thing is to be creative', Joe explains. Casandra echoes this idea when she suggests that other sewers, or fabric workers, with the skills she requires, would do nothing for her, she sees herself as an artist, and needs artists around her. Grabher (2002) may see this as a form of temporary collaboration (particularly in the case of the Australian artists on work visas) and socialisation within creative clusters (Heebels \& Van Aalst, 2010), the artists are becoming encultured, as they learn how to behave as artists in a place where they 'don't feel locked away'.

This learning, however, does not translate into developing their craft in a commercial sense. For example, Casandra explains that she does not know how to price her art by retelling a story of being overwhelmed by a customer asking for price. After a fluster and much embarrassment, the customer ultimately left the studio without Casandra's piece. Joe suggests that selling is in no way a priority, 'I haven't tried selling from here. People often come in and ask how much, and I think what I tell them is often way out of their price range'. Instead, he sees the artist's network as the important channel of distribution (Anderson \& Jack, 2002), particularly in terms of the commercial activity of pricing, 'the best way to sell is through a gallery, because galleries have contacts, people that will pay what I want for it'.

However, an awareness of commercial skills seems far from the artists' minds as they focus on personal over market opportunities. Steve clarifies he is, 'not trying to work for something stable, or an income, I'm going to do what I want to do'. While Joe is a little more reflective, by saying, 'I've got a fear of regret of not trying... you can always find a way to survive', and therefore commercial activity is not required. 'I'm not down to do something in art that I don't want to do [off-the-street sales] to fund something that I do want to do. If it's going to create bad art, art that I'm not proud of, then I wouldn't [do it]'. The artists explain their desire for success, but admit that they are unsure what would have to develop to make them successful. 'I've always wanted to come here and do what I'm doing', says Steve, who previously ran his own successful tennis coaching business. 'If I done well out of Berlin, I'd stay here and do it'.

\subsection{The Intermediary}

'The majority of my friends and artists who I really admired... were suddenly declining in their career. They were failing and this was harming me - my self-definition - as an artist, so I thought, since I'm able to communicate and also to sell, I'll take over'. Lars explains why he felt he had to start an instillation art gallery to help the other artists maintain their careers in a squeezed middle of the market. In doing so, he sacrificed his own art production. He rationalises that his business will survive or fail on his ability to build the careers of the artists he 'represents', echoing Anderson et al.'s (2010) ideas on the co-creation of entrepreneurship through networked practices. At the photography gallery across the street, in the residentially plush area of Berlin's Mitte, Natalia offers a similar sentiment as she helps the artists 'where they're not very good. Sometimes they're not very good communicating with the people who have the money, or the institutions. I help with money, with contacts, I see myself as their networker'. Though she seems to find it clichéd to present it as a familial relationship with the photographers, she does emphasise the personal 
connection that is needed to mentor and help with all sorts of issues, such as money and career, over and above what is going on in the gallery. A 'community of interests', as she puts it, 'bringing people together... you can find creativity here, but it is easy to get lost. Partying and going to openings, you know, you can end up not concentrating on what you wanted to do. The artists don't want to talk about business, but I have to, otherwise it's not going to happen'.

There seems to be something of 'the artist's saviour' in how both these galleries go about their business. Lars is especially reflective on this, suggesting that while 'Germany is a land of philosophers and poets, the contemporary scene is not necessarily endorsed'. Though there is cultural interest in the arts, this is only economically viable if that artist can 'breakthrough' into known success and be taken seriously. For Lars and Natalia, they appear to position themselves so as to facilitate this 'breakthrough', reminiscent of 'breaking-out' of social enclaves in the embeddedness literature (Ram \& Hillin, 1994). 'It's more cooperation than competition... as a photographer it can be very lonely', Natalia proclaims as she recounts the story of an international magazine who used a Munich-based gallery in an attempt to engage with the Berlin market and was met with fierce resistance. Thus, 'coopetition' within the scene seems more orientated towards a protection of territory, than to the creation of opportunities (Bengtsson \& Johansson, 2014). In fact, the notion of resistance echoes when discussing other aspects of the creative scene. Lars claims, 'the authorities don't really know what's going on...we have this crisis in the art market, but because I'm leidensfäig (masochistic), I can survive it', pointing specifically to the rise of VAT on works of art. While Natalia points to a cultural negativity, saying some see it '[as if] there is nothing else you could do. People in Germany don't like it, they want you all to be the same... others, they have a picture of something creative, and they don't know that it's hard work to make that happen. They consider me as an artist, because I work with artists, but you know, I'm the organising person'.

Both are rooted in the city and consider it the main cultural driver of what they do, mostly down to the in-expense of the city as a pull factor for creativity. But also, Lars considers Berlin the freest city in the world, where you can do what you want, there is no limitation'. Natalia suggests it is unlike the many other 'closed' cities she has worked in since leaving East Germany, as it's so 'easy to meet people, there are so many cultural events, so many exhibitions'. The importance of place is accentuated here (Johnstone \& Lionais, 2004), where 'Berlin has the energy', in terms of money, the galleries are struggling. Lars explains that while there may be support for artists to produce, there is no support for selling, nothing to make the cultural production economically viable. 'It is a long and painful process' to sell art in a cash-strapped Berlin, Lars laments. However, both feel an admiration and support from those involved in the creative scene as they 'know how difficult it is', according to Lars. Specifically, Natalia, connects the support for creative photography with an East Germany tradition for capturing social life, suggesting that her main investor did not need convincing in this regard as he 'got it'. Lars also sees a lot of influence from history, in the destruction of the fashion industry after World War II, meaning that a new creative scene had to be built from the grassroots level. It is perhaps because of this collective building of the scene that Natalia claims 'it is very easy to fit in a creative network, it immediately feels like friends and family. There was so much freedom and love and creativity, I just... I'll always remember how much love and fun and luckiness I felt [coming from East Germany]. I had no money and a daughter... worst case scenario in a way... but Berlin was really like a soft cushion'.

Lars and Natalia are quick to explain the organisation and business skills it has taken to position their enterprises. 'It's a lot of work... it's a very risky undertaking, and it still is', Lars convincingly 
argues as he tells of the training seminars and hours it took to provide an investment-worthy business plan. 'It's crazy bureaucracy [to start a business in Germany]... and people don't want to do it, because it's very easy to be employed', states Natalia as she thinks of her own motivations. 'This is a very long term business, most people fail... across the street, there was a gallery, they went bankrupt... I am still here', says Lars as he considers the sustainability of the business.

\subsection{The Commercialised Business}

Sonya and Toni have a studio/store on the same street as Lars' and Natalia's galleries, however the way the run their enterprise seems a long way from being embedded in the Berlin scene. The bespoke statement blankets they design are produced in South Africa, and represent an international supply chain more in common with multi-national corporations than the creative locale. In fact, they purposeful deny the Berlin aspects of their work, 'when we are in other cities, we don't really tell them we are from Berlin, or they think... a lot of things are just blah, blah'. They find the relationship with Berlin a difficult one to reconcile, 'everybody does something cool here, when you walk down the street, everybody does something creative... it's kind of difficult to get a reputation that you are in fact beyond that, where people really take you seriously. That's what I think. The Berlin thing is not really in our focus, we hope to be taken seriously'.

Commercial skills dominate the discussions for these two: from the initial identification of market opportunity for individually designed blankets, to realising 'there are not very many really nice ones, or not many nice ones of very good quality... We are selling a moment'. The conversation focuses a lot on seeking skills from other places. 'Our connections are everywhere, it's not important to be part of a Berlin community at all. I think it's more important to know who you can ask for what kind of questions, where he is, it doesn't matter, it's just important that he knows the answer'. But also, they seem very concerned with professionalising the way things are run, 'we have a very detailed contract [with best friend business partner], what happens if somebody dies, or somebody gets pregnant, or whatever, yeah, we plan to do it really long term, if we can'. And importantly, how things sell, 'we have an online shop, it doesn't work very well yet, it just takes a bit of time for people to go on the website and look for it and buy it'. Developing a competence portfolio is important for this business (Mietzner \& Kamprath, 2013), affording them the confidence to move beyond the Berlin market and into broader growth areas.

As with Lars and Natalia, Sonya and Toni stress the difficulties of starting and sustaining the business. However, in this case, there is more emphasis on maintaining growth, rather than surviving to benefit their surroundings. 'We started two years ago, but we needed almost a year to produce first prototypes and look for producers, and of course all the legal trademark things. We started selling to shops last year... My father comes from a family company, he was very encouraging. He's always the one saying you have to take risks'. The view is to expand as quickly as is sustainably possible, using international networks to gain knowledge, but also as a vehicle for market growth (Naldi \& Davidsson, 2014). The art in this business is seen as the key differentiator in the market, but there is flexibility more typically associated with small firms in the traditional sectors, Sonya explained, 'I was scared that nobody would buy the blankets in the store... I was always worried, if people don't like it, then how could I do it better'. Sonya, providing the artistic direction, and Toni providing a certain level of business acumen, focus solely on commercial growth and combining resources in the most efficient way possible. While Sonya has a background in design, the work with textiles is new, as was the perceived market want, this shift 
away from the intrinsic artist to a market pull orientation is sharp in its contrast to others in Berlin's creative scene.

\subsection{Mapping the scene}

We use the three forms of cultural producer found through this small ethnography, to apply a mixed embeddedness lens and begin to sketch out how each individual is socially embedded in the creative context of Berlin. This sketch is then used to identify the role entrepreneurship plays in the creative scene, and allows us to focus in a more targeted fashion on those entrepreneurs who link the artistic and the commercial cultures.

First, it would seem that the artists themselves are firmly embedded in the artistic and creative culture, to such an extent that for many it is the reason they are in Berlin, to soak up artistic inspiration. Lack of priority in selling, or the absence of any ability to engage with interested parties, clearly shows that the commercialisation of their art is far from their mind. Therefore, our artists seem to occupy a creative enclave, supporting one another, but often far from the market which can economically sustain them. Second, the intermediary (in the form of galleries in this case) seems to purposefully break out of the creative enclave in order to engage with the more commercially oriented culture. While they may be more embedded in the artistic world than the commercial, and value the creative process rather than the business, they consider themselves to be the defenders of Berlin's vulnerable artistic soul. Finally, the commercially creative business appears as fully focused on market needs and is willing to use their individual creativity to satisfy said needs. There is limited, if any, engagement with the surrounding creative scene and, in fact, seems troubled by the idea of being shackled to creative cultures. This sketch of the scene may be visualised in Figure 1.

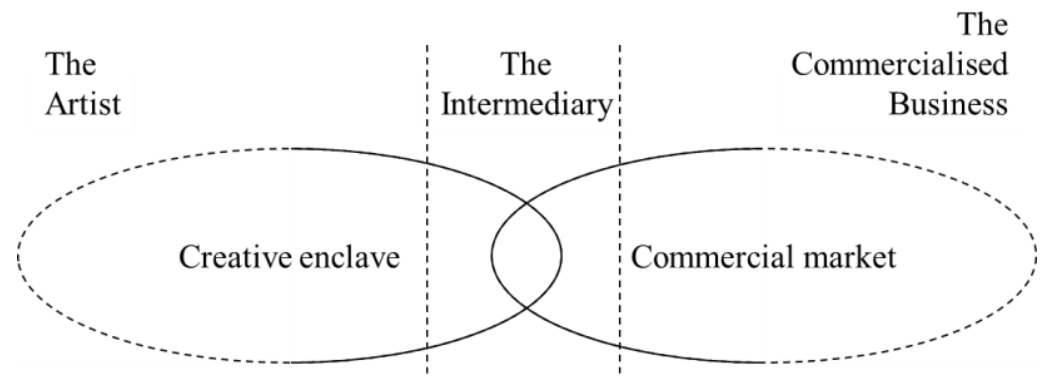

Figure 1: Sketch of Berlin's embedded artists

For the purposes of this study, and in order to investigate the role entrepreneurship plays in the functioning of Berlin's creative scene, the second stage of the investigation looks to examine further the identity of those intermediary entrepreneurs, positioned at the nexus of the creative and the commercial worlds. Thus, we look to explore those entrepreneurial entities dually embedded in both artistic and commercial cultures as helping us understand the limited economic success of Berlin's abundant creative industries. 
After identifying the intermediary as a key entity to understand entrepreneurial embeddedness in Berlin's artistic scene, we specifically focus on this character. We attempt to uncover how their identity is constructed, and what they see as their role. The themes we find are summarised in Figure 2, these are discussed against the backdrop of our stage one findings and the extant literature on entrepreneurship in context.

The first aspect worthy of attention is that the vast majority of entrepreneurs represented in our sample function as a form of hybrid-business, in the same way that Ebrahim et al. (2014) and Doherty et al. (2014) describe the dual agendas of social enterprises. They integrate the creative elements of their surroundings, for instance, the sale of art, photography, original music and literature, with a more traditional commercial arena, such as a café or events venue. As such, there is immediately a tension between the cultural and market logic of their business goals (Battilana et al., 2012). While these enterprises may not be in the service of the disadvantaged, as with social enterprise, they do appear to service the artistic, often at the de-prioritisation of financial outcomes (Zahra et al., 2009). So, far from Jones's (2007) worry of mission drift, as the commercial features of the enterprise bully out the social in non-profits, these profit-seeking entities appear to emphasise the creative as their main value, allowing the commercial to wane. This cultural agenda takes form as a desire to bring people together through the integration of creative arts in their enterprise, the entrepreneurs view this as their main contribution.

You can use capitalistic entrepreneurial investment to have greater goals that go beyond making money. It's this compassionate capitalism or capitalism with a cause... have we contributed to the creative scene? Yes, by seeing the fruit of it... we can give them the opportunity to do that, even though it doesn't make financial sense for us, but it covers the things we care about (E8)

We could claim that our intermediary entrepreneurs follow artistic logic by putting in more effort to bring together people through art, than they will receive economic reward (Caves, 2000). While this clearly aligns our entrepreneurs with the creative enclave, it also holds the potential to, often purposefully, limit the enterprise in terms of growth ambition (Colbert, 2006). Rich cultural capital then, instead of providing resource of economic value, can be seen to isolate and 'protect' the enterprises from more commercial societies (Light \& Dana, 2013). For example, it seems that our entrepreneurs look to protect their cultural impact by not moving beyond certain boundaries, even geographical in nature.

In one sense, the gentrification here, we are part of it because we are changing... on the other hand, I think we are contributing [locally] to Neuköln itself to develop and to change, maybe not to change to a high-class, posh, or whatever, but to a creative, for young people, area (E6)

There are many people coming in who want to do something that they believe would actually keep the culture and create some kind of cultural value in Wedding... we want to create some kind of organisation which would be able to help new spaces, independent spaces $(\mathrm{E} 2)$ 


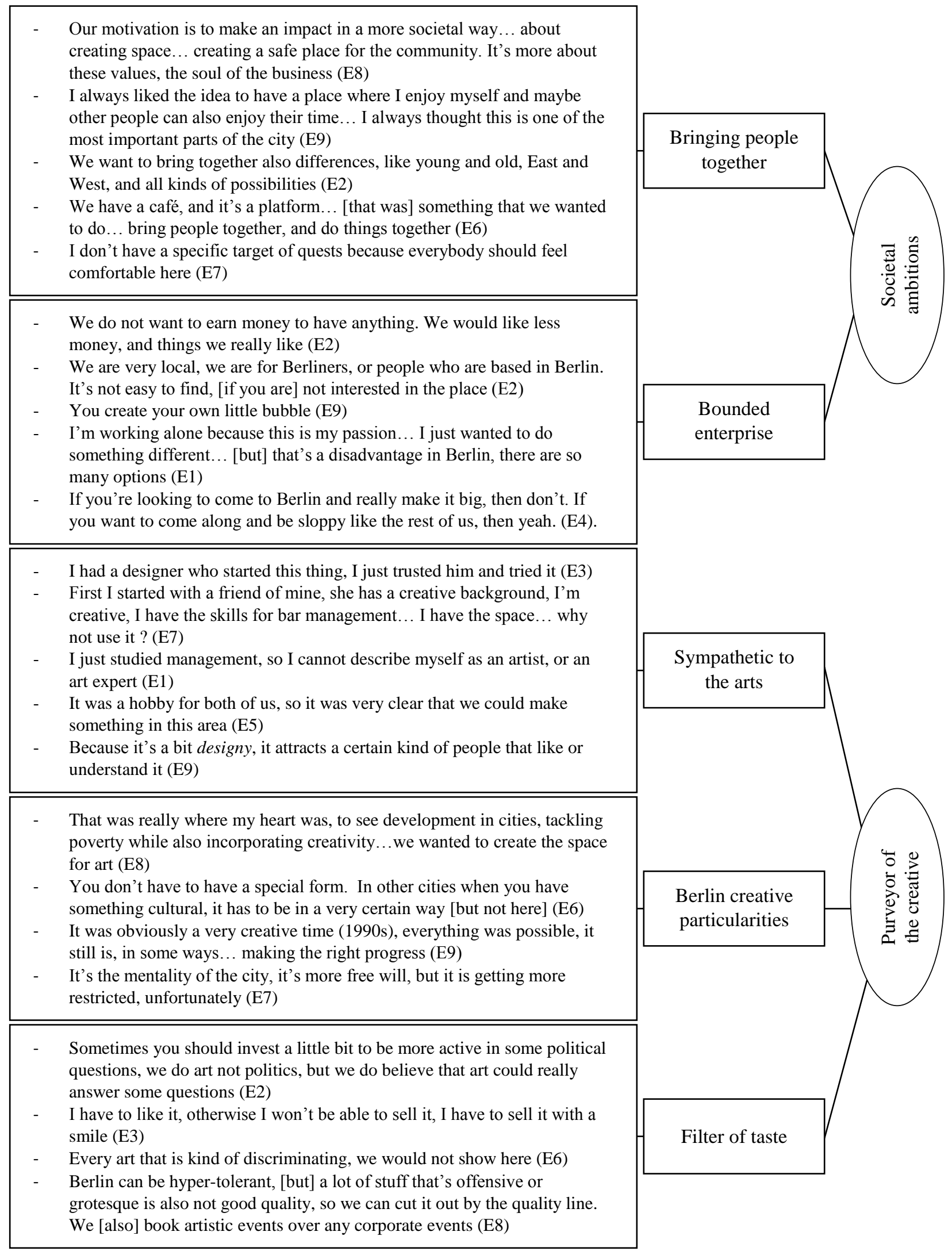

Figure 2: Stage two data structure 
Importantly, many of our entrepreneurs stress the importance of their role in the diversity of Berlin, and running a 'safe place' for the many peoples of the area to come and participate. One perspective may be to see their entrepreneurship as a form of subservience against social resistance to new and integrative ideas (Berglund \& Gaddefors, 2010; Bureau \& Zander, 2014). The form of innovative creativity in the minds of these entrepreneurs is not the sort to disrupt industries or advance technical ability, but instead focuses on a form of social innovation (Lisetchi \& Brancu, 2014), by bringing together different elements of society. Critically, there are no explicit social objectives here, as in a conceptualisation of social entrepreneurship (Peredo \& McLean, 2006), but our entrepreneurs have the idea that they "want to make it special" (E7), as if realising a higher purpose, from the political to the humanitarian.

Once a month there's a queer creations evening, there are a couple of trans events... there's a set of shared values around queer events... we also have occasional refugee events, it's just hard to see it as a separate process (E2)

Economic rationale is thus quite distant from our entrepreneurs' constructed identity. In this context, entrepreneurship is very unlike that implied by Shane and Venkataraman's (2000) views on economic opportunity. A novel, more culturally-led entrepreneurship comes to the fore, one which responds directly to the perceived needs of the local community, and adopts the behavioural norms and expectations of this community appropriately (Welter, 2006).

As part of their context-specific entrepreneurial agenda, our entrepreneurs' role in the creative scene is also examined. There appears to be an initial 'induction' to artistic cultures, via hobby or creative partners and connections. Our entrepreneurs think of themselves as bringing this creative character of Berlin out. In this sense, they may act as cultural gatekeepers, determining the value of cultural production, allowing exposure to commercial markets (Currid, 2007). Individuals at the genesis of artistic production are able to exchange ideas, via the platform our entrepreneurs create, to build reputation and impact in the cultural community (Heebels \& Van Aalst, 2010). As gatekeepers, they represent the field to the wider community, in an interactive process of cultural production (Csikszentmihalyi, 1999). However, some support is found for Fillis and Rentschler's (2010) notion that this process is not always liner. Our entrepreneurs also feel that they are part of the creativity of the scene as they rationalise their role, not as an artist, but in the production and consumption of the final output (Neff et al., 2005).

These people (customers attracted to the store) have open minds and they come to the shop and they buy the furniture, most are looking and are fascinated (E5)

I wouldn't call myself an artist... we are not the artists ourselves, but we have the space... I think artists should have the idea themselves, I'm more reproducing (E6)

However, there is also a sense that these intermediary actors in the creative process have more of an active impact than simply transmitting the intentions of the cultural producers. Our entrepreneurs filter which creative ideas are permitted to pass through their enterprise, not on lines of usefulness or value, as seen with technology entrepreneurs (Gemmell et al., 2012), but instead, seem to accept or decline cultural production against their own innate beliefs, even ideologies. From a mixed embeddedness perspective, it seems our entrepreneurs do indeed see the artist 
enclave as a resource of "very interesting people" (E2), however, it could be suggested that they also see their role as one of control over what is accepted for consumption by the broader community. Perhaps this is connected to the saturation of artistic Berlin, a point raised by many of our entrepreneurs. The intermediary figure may act as a quality control on what would otherwise be a creative free-for-all, some form of structure and consistency in an otherwise transient and purposefully unstructured artistic community.

\section{Every place [has become] replaceable, there are too many artists here. There is a vibe, but there's also too many of them here (E7)}

\section{Conclusions}

We borrow from the literature on ethnic minority entrepreneurship and apply a mixed embeddedness lens to our research problem, the limited economic growth of Berlin's vibrant and well-regarded creative industries. Economic theory on the development of urban areas through creative clustering does not explain such a situation. However, by answering Lange et al.'s (2008) call to greater understand how the creative scene in Berlin functions, we uncover various interactions and roles to provide us with an alternative explanation for this economic puzzle. We find a key role in the commercialisation and growth of cultural producers in the Berlin scene to be that of the intermediary. These firms, often hybrid in nature, grapple with a dual purpose, to maintain a commercially viable enterprise, while also achieving their goals of artistic and cultural inclusion. We find entrepreneurs in these businesses to exist at the nexus of the artistic and marketbased cultures. However, as opposed to providing a necessary translation of creative artefact to commercial product, they appear to interact greatly with their social and spatial context and as such take on a somewhat novel approach to entrepreneurial behavior.

The cultural agenda of these crucial enterprises looms large in how they conduct their business, the cultural needs of 'place' identity dominant any individualised economic goals (Dana et al., 2014). This is manifest in the decisions they take, for instance: on which cultural productions to include in their offering; which types of people they cater for; and the often politicised ideas on which causes should be represented. As a result, the key enablers of Berlin's creative industries de-prioritize economic goals in order to focus on what they see as their responsibility for maintaining the quality and direction of Berlin's creative soul.

Our key contribution here lies in the use of mixed embeddedness to uncover an entrepreneurial character ill-explained by traditional economic theory. Our creative entrepreneurs are driven by a multitude of often conflicting issues, many of which appear as a direct reaction to what they interpret as cultural, even societal issues. Thus we advance our understanding of entrepreneurship in the creative industries beyond that of the commercialised individual artist, or even that of a network of value-adding processes, to something that is more ideologically determined. A phenomenon that reacts to its surrounding, and in doing so, plays an active role in shaping it.

Any work of this nature has many limitations, foremost of these is that we cannot claim to have represented all aspects of Berlin's artistic scene. However, with the staged approach to research design, we have been able to uncover a curiosity of entrepreneurial behaviour at what we see as a crucial point of the creative process. Future works, however, may wish to look more closely at those cultural producers firmly embedded in artistic enclaves. From our ethnographical sketch there are suggestions that these individuals actively avoid engaging with commercial structures, however, more investigation is needed here, particularly in terms of what this means for the creative scene as a whole. Moreover, there are many suggestions in our data and the extant 
literature that Berlin's creative scene is unique, but it would be interesting to examine how the nature of creative entrepreneurship differs with setting. Would other seemingly creative cities harbour the same entrepreneurial mix in terms of embeddedness?

While our findings cannot be generalized to other areas, we have highlighted the role of context, and of social embeddedness, lending to calls to move beyond universalistic economic understandings of entrepreneurship (Anderson, 2015). This aspect of our findings is likely to be replicated elsewhere, but the results for entrepreneurship will depend entirely on the specificities of context.

\section{References}

Alvesson, M. and Deetz, S. (2000) Doing critical management research, Sage, London.

Anderson, A.R. (2015). Conceptualising entrepreneurship as economic "explanation" and the consequent loss of "understanding", International Journal of Business and Globalisation, Vol. 14, No. 2, pp.145-157.

Anderson, A.R. and Jack, S.L. (2002) 'The articulation of social capital in entrepreneurial networks: a glue or a lubricant?', Entrepreneurship and Regional Development, Vol. 14, No. 3, pp.193-210.

Anderson, A.R., Dodd, S. D. and Jack, S.L. (2010) 'Network practices and entrepreneurial growth', Scandinavian Journal of Management, Vol. 26, No. 2, pp.121-133.

Atkinson, R. (2003) 'Gentrification in a new century: misunderstood saviour or vengeful wrecker? What really is the problem with gentrification?', Urban Studies, Vol. 40, No. 12, pp.23432350.

Baker, T. and Nelson, R.E. (2005) 'Creating something from nothing: Resource construction through entrepreneurial bricolage', Administrative Science Quarterly, Vol. 50, No. 3, pp.329366.

Baker, T. and Powell, E. (2016) 'Let them eat bricolage? Towards a contextualised notion of inequality of entrepreneurial opportunity', In Welter F. and Gartner W.B. (Eds.), A research agenda for entrepreneurship and context, Edward Eglar, Cheltenham, pp.41-53.

Barrett, G.A., Jones, T.P. and McEvoy, D. (2001) 'Socio-economic and policy dimensions of the mixed embeddedness of ethnic minority business in Britain', Journal of Ethnic and Migration Studies, Vol. 27 No. 2, pp.241-258.

Battilana, J., Lee, M., Walker, J. and Dorsey, C. (2012) 'In search of the hybrid ideal', Stanford Social Innovation Review, Vol. 10, No.3, pp.50-55.

Bengtsson, M. and Johansson, M. (2014) 'Managing coopetition to create opportunities for small firms', International Small Business Journal, Vol. 32, No. 4, pp.401-427.

Berglund, K. and Gaddefors, J. (2010) 'Entrepreneurship demands resistance to be mobilized', In Bill, F., Bjerke, B. and Johansson A.W. (Eds.) (De)Mobilizing the entrepreneurship discourse, Edward Elgar, Cheltenham.

Bruni, A., Gherardi, S. and Poggio, B. (2004) 'Doing gender, doing entrepreneurship: An ethnographic account of intertwined practices', Gender, Work and Organization, Vol. 11, No. 4, pp.406-429.

Bureau, S. and Zander, I. (2014) 'Entrepreneurship as an art of subversion', Scandinavian Journal of Management, Vol. 30, No. 1, pp.124-133.

Calás, M.B., Smircich, L. and Bourne, K.A. (2009) 'Extending the boundaries: Reframing 'entrepreneurship as social change' through feminist perspectives', Academy of Management Review, Vol. 34, No. 3, pp.552-569. 
Caves, R. (2000) Creative industries: Contacts between art and commerce, Harvard University Press, Cambridge, MA

Chlosta, S. (2016) 'Methodological approaches towards context-sensitive entrepreneurship research', In Welter F. and Gartner W.B. (Eds.) A research agenda for entrepreneurship and context, Edward Eglar, Cheltenham, pp.109-119.

Colbert, F. (2003) 'Entrepreneurship and leadership in marketing the arts', International Journal of Arts Management, Vol. 6, No. 1, pp.30-39.

Colbert, F. (2006) 'Unternehmertum und Führung im Marketing von Kunst und Kultur', In Konrad E.D. (Ed.), Unternehmertum und Führungsverhalten im Kulturbereich, Waxmann, Göttingen, pp.189-204.

Colbert, F. and Courchesne, A. (2012) 'Critical issues in the marketing of cultural goods: The decisive influence of cultural transmission', City, Culture and Society, Vol. 3, No. 4, pp.275280.

Cologne Institute for Economic Research (2016) 'The capital city effect', available via: https://www.iwkoeln.de/en/press/iwd/beitrag/gross-domestic-product-the-capital-city-effect296876 (Accessed 10 May 2017).

Corbin, J.M. and Strauss, A. (1990) 'Grounded theory research: Procedures, canons, and evaluative criteria', Qualitative Sociology, Vol. 13, No. 1, pp.3-21.

Csikszentmihalyi, M. (1999) 'Implications of a systems perspective for the study of creativity', In Sternber R.J. (Ed.), Handbook of Creativity, Cambridge University Press, New York, pp.313335

Currid, E. (2007) The Warhol economy: how fashion, art, and music drive New York City, Princeton University Press, Princeton, NJ.

Dana, L.P. and Dana, T.E. (2005) 'Expanding the scope of methodologies used in entrepreneurship research', International Journal of Entrepreneurship and Small Business, Vol. 2, No. 1, pp.7988.

Dana, L.P., Gurau, C., and Lasch, F. (2014) 'Entrepreneurship, tourism and regional development: a tale of two villages', Entrepreneurship \& Regional Development, Vol. 26, No. 3-4, pp.357374.

Doherty, B., Haugh, H. and Lyon, F. (2014) 'Social enterprises as hybrid organizations: A review and research agenda', International Journal of Management Reviews, Vol. 16, No. 4, pp.417436.

Drake, G. (2003) “'This place gives me space': Place and Creativity in the Creative Industries', Geoforum, Vol. 34, No. 4, pp.511-524.

Ebrahim, A., Battilana, J. and Mair, J. (2014) 'The governance of social enterprises: mission drift and accountability challenges in hybrid organizations', Research in Organizational Behavior, Vol. 43, pp.81-100.

Eikhof, D.R., Haunschild, A. (2006) 'Lifestyle meets market: bohemian entrepreneurs in creative industries', Creativity and Innovation Management, Vol. 15, No. 3, pp.234-241.

Ellmeier, A. (2003) 'Cultural entrepreneurialism: on the changing relationship between the arts, culture and employment', The International Journal of Cultural Policy, Vol. 9, No. 1, pp.316.

Ertel, R. (2006) 'Daten und Fakten zur Kulturwirtschaft', Aus Politik und Zeitgeschichte, No. 34$35, \mathrm{pp} .17-23$.

Fillis, I. (2003) 'Image, reputation and identity issues in the arts and crafts organization', Corporate Reputation Review, Vol. 6, No. 3, pp.239-251. 
Fillis, I. and Rentschler, R. (2010) 'The role of creativity in entrepreneurship', Journal of Enterprising Culture, Vol. 18, No. 1, pp.49-81.

Fletcher, D. and Selden, P. (2016) 'A relational conceptualization of context and the real-time emergence of entrepreneurship processes', In Welter F. and Gartner W.B. (Eds.) A research agenda for entrepreneurship and context, Edward Eglar, Cheltenham, pp.79-92.

Florida, R. (2014) 'The creative class and economic development', Economic Development Quarterly, Vol. 28, No. 3, pp.196-205.

Ganzaroli, A., Orsi, L. and De Noni, I. (2013) 'The evolution of the social understanding of ethnic entrepreneurship: results from a bibliometric analysis of the literature', International Journal of Entrepreneurship and Small Business, Vol. 20, No. 4, pp.383-401.

Gedajlovic, E., Honig, B., Moore, C.B., Payne, G.T. and Wright, M. (2013) 'Social capital and entrepreneurship: A schema and research agenda', Entrepreneurship Theory and Practice, Vol. 37, No. 3, pp.455-478.

Gemmell, R.M., Boland, R.J. and Kolb, D.A. (2012) 'The socio-cognitive dynamics of entrepreneurial ideation', Entrepreneurship Theory and Practice, Vol. 36, No. 5, pp.10531073.

Glaser, B.G. and Strauss, A.L. (1967) The discovery of grounded theory, Aldine, Chicago.

Grabher, G. (2002) 'Cool projects, boring institutions: temporary collaboration in social context', Regional Studies, Vol. 36, No. 3, pp.205-214.

Granovetter, M. (1985) 'Economic action and social structure: The problem of embeddedness', American Journal of Sociology, Vol. 91, No. 3, pp.481-510.

Harvey, D. (2001) Spaces of capital: Towards a critical geography, New York, Routledge.

Hausmann, A. (2010) 'German artists between Bohemian idealism and entrepreneurial dynamics: Reflections on cultural entrepreneurship and the need for start-up management', International Journal of Arts Management, Vol. 12, No. 2, pp.17-29.

Heebels, B., and Van Aalst, I. (2010) 'Creative clusters in Berlin: Entrepreneurship and the quality of place in Prenzlauer Berg and Kreuzberg', Geografiska Annaler: Series B, Human Geography, Vol. 92, No. 4, pp.347-363.

Helbrecht, I. (2004) 'Bare geographies in knowledge societies-creative cities as text and piece of art: two eyes, one vision', Built Environment, Vol. 30, No. 3, pp.194-203.

Hoang, H. and Antoncic, B. (2003) 'Network-based research in entrepreneurship: A critical review', Journal of Business Venturing, Vol. 18, No. 2, pp.165-187.

Johnstone, H. and Lionais, D. (2004) 'Depleted communities and community business entrepreneurship: revaluing space through place', Entrepreneurship and Regional Development, Vol. 16, No. 3, pp.217-233.

Jones, M.B. (2007) 'The multiple sources of mission drift', Nonprofit and Voluntary Sector Quarterly, Vol. 36, No. 2, pp.299-307.

Kloosterman, R. and Rath, J. (2001) 'Immigrant entrepreneurs in advanced economies: mixed embeddedness further explored', Journal of Ethnic and Migration Studies, Vol. 27, No. 2, pp.189-201.

Kloosterman, R., Van der Leun, J.P. and Rath, J. (1999) 'Mixed embeddedness, migrant entrepreneurship and informal economic activities', International Journal of Urban and Regional Research, Vol. 23, No. 2, pp.253-267.

Kloosterman, R.C. (2010) 'Matching opportunities with resources: A framework for analysing (migrant) entrepreneurship from a mixed embeddedness perspective', Entrepreneurship and Regional Development, Vol. 22, No. 1, pp.25-45. 
Kloosterman, R.C. and Van der Leun, J.P. (1999) 'Just for starters: commercial gentrification by immigrant entrepreneurs in Amsterdam and Rotterdam neighbourhoods', Housing Studies, Vol. 14, No. 5, pp.659-677.

Konrad, E.D. (2013) 'Cultural entrepreneurship: the impact of social networking on success', Creativity and Innovation Management, Vol. 22, No. 3, pp.307-319.

Lange, B., Kalandides, A., Stöber, B. and Mieg, H.A. (2008) 'Berlin's creative industries: governing creativity?', Industry and Innovation, Vol. 15, No. 5, pp.531-548.

Lee, S.Y., Florida, R. and Acs, Z. (2004) 'Creativity and entrepreneurship: a regional analysis of new firm formation', Regional Studies, Vol. 38, No. 8, pp.879-891.

Light, I. and Dana, L.P. (2013) 'Boundaries of social capital in entrepreneurship', Entrepreneurship Theory and Practice, Vol. 37, Vol. 3, pp.603-624.

Lisetchi, M. and Brancu, L. (2014) 'The entrepreneurship concept as a subject of social innovation', Procedia-Social and Behavioral Sciences, Vol. 124, pp.87-92.

Lounsbury, M., and Glynn, M. A. 2001. 'Cultural entrepreneurship: Stories, legitimacy, and the acquisition of resources', Strategic Management Journal 22(6-7), pp. 545-564.

Masurel, E., Nijkamp, P., Tasan, M. and Vindigni, G. (2002) 'Motivations and performance conditions for ethnic entrepreneurship', Growth and Change, Vol. 33, No. 2, pp.238-260.

McKeever, E., Anderson, A.R. and Jack, S.L. (2014) 'Social embeddedness in entrepreneurship research: the importance of context and community', In Chell, E. and Karataş-Özkan, M. (Eds.), Handbook of Research on Small Business and Entrepreneurship, Edward Elgar, Cheltenham, pp.222-236

Menger, P.M. (1999) 'Artistic labor markets and careers', Annual Review of Sociology, Vol. 25, No. 1, pp.541-574.

Mietzner, D. and Kamprath, M. (2013) 'A competence portfolio for professionals in the creative industries', Creativity and Innovation Management, Vol. 22, No. 3, pp.280-294.

Montgomery, J. (2005) 'Beware 'the creative class'. Creativity and wealth creation revisited', Local Economy, Vol. 20, No. 4, pp.337-343.

Naldi, L., and Davidsson, P. (2014) 'Entrepreneurial growth: The role of international knowledge acquisition as moderated by firm age', Journal of Business Venturing, Vol. 29, No. 5, pp.687703.

Neff, G., Wissinger, E. and Zukin, S. (2005) 'Entrepreneurial labor among cultural producers: 'Cool' jobs in 'hot' industries', Social Semiotics, Vol. 15, No. 3, pp.307-334.

Novy, J. and Colomb, C. (2013) 'Struggling for the right to the (creative) city in Berlin and Hamburg: new urban social movements, new 'spaces of hope'?', International Journal of Urban and Regional Research, Vol. 37, No. 5, pp.1816-1836.

Peltoniemi, M. (2009) 'Entrepreneurship and innovation within creative industries: a case study on the Finnish games industry', International Journal of Entrepreneurship and Small Business, Vol. 7, No. 4, pp.420-430.

Peredo, A.M. and McLean, M. (2006) 'Social entrepreneurship: A critical review of the concept', Journal of World Business, Vol. 41, No. 1, pp.56-65.

Phillips, R.J. (2010) 'Arts entrepreneurship and economic development: can every city be 'Austintatious'?', Foundations and Trends in Entrepreneurship, Vol. 6, No. 4, pp.239-313.

Pret, T., Shaw, E. and Drakopoulou Dodd, S. (2016) 'Painting the full picture: The conversion of economic, cultural, social and symbolic capital', International Small Business Journal, Vol. 34, No. 8, pp.1004-1027. 
Ram, M. and Hillin, G. (1994) 'Achieving 'break-out': developing mainstream ethnic minority businesses', Journal of Small Business and Enterprise Development, Vol. 1, No. 2, pp.15-21.

Ram, M. and Jones, T. (2008) 'Ethnic-minority businesses in the UK: a review of research and policy developments', Environment and Planning C: Government and Policy, Vol. 26, No. 2, pp.352-374.

Rusinovic, K. (2008) 'Moving between markets? Immigrant entrepreneurs in different markets', International Journal of Entrepreneurial Behavior and Research, Vol. 14, No. 6, pp.440-454.

Sarasvathy, S.D. (2001) 'Causation and effectuation: Toward a theoretical shift from economic inevitability to entrepreneurial contingency', Academy of Management Review, Vol. 26, No. 2, pp.243-263.

Schmude, J., Welter, F. and Heumann, S. (2008) 'Entrepreneurship research in Germany', Entrepreneurship Theory and Practice, Vol. 32, No. 2, pp.289-311.

Senatsverwaltung für Wirtschaft und Technologie (2014) 'Dritter Kreativwirtschaftsbericht: Entwicklungen und Potenziale', Available via: https://www.berlin.de/sen/kultur/kulturpolitik/ kulturwirtschaft/ (Accessed 10 Oct 2017).

Shane, S. and Venkataraman, S. (2000) 'The promise of entrepreneurship as a field of research', Academy of Management Review, Vol. 25, No. 1, pp.217-226.

Silverman, D. (2013) Doing qualitative research: A practical handbook, SAGE, London.

Smallbone, D. and Welter, F. (2006) 'Conceptualising entrepreneurship in a transition context', International Journal of Entrepreneurship and Small Business, Vol. 3, No. 2, pp.190-206.

Storper, M. and Venables, A.J. (2004) 'Buzz: face-to-face contact and the urban economy', Journal of Economic Geography, Vol. 4, No. 4, pp.351-370.

Swedberg, R. (2006) 'The cultural entrepreneur and the creative industries: beginning in Vienna', Journal of Cultural Economics, Vol. 30, No. 4, pp.243-261.

Tamasy, C. (2010) 'Nascent entrepreneurs and the regional context', International Journal of Entrepreneurship and Small Business, Vol. 10, No. 2, pp.205-223.

Tironi, M. (2009) 'The paradoxes of cultural regeneration: Artists, neighbourhood redevelopment and the 'creative city' in Poblenou, Barcelona', Journal of Urban Regeneration and Renewal, Vol. 3, No. 1, pp.92-105.

Tregear, A. (2003) 'Market orientation and the craftsperson', European Journal of Marketing, Vol. 37, No. 11-12, pp.1621-1635.

Van Gelderen, M., Masurel, E. and Verduyn, K. (2012) 'Introduction to 'Entrepreneurship in Context', In Van Gelderen, M. and Masurel, E. (Eds.), Entrepreneurship in Context, Routledge, London, pp.1-22.

Welter, F. (2006) 'Entrepreneurship in West and East Germany', International Journal of Entrepreneurship and Small Business, Vol. 4, No. 2, pp.97-109.

Welter, F. (2011) 'Contextualizing entrepreneurship — conceptual challenges and ways forward', Entrepreneurship Theory and Practice, Vol. 35, No. 1, pp.165-184.

Westlund, H. and Bolton, R. (2003) 'Local social capital and entrepreneurship', Small Business Economics, Vol. 21, No. 2, pp.77-113.

Zahra, S.A., Gedajlovic, E., Neubaum, D.O. and Shulman, J.M. (2009) 'A typology of social entrepreneurs: Motives, search processes and ethical challenges', Journal of Business Venturing, Vol. 24, No. 5, pp.519-532. 